\title{
Le pays dans la poésie de Char de 1946 à 1970, «René Char», 1. Texters réunis par Patrick Née et Danièl Leclair
}

\section{Emanuele Kanceff}

\author{
(2) OpenEdition \\ Journals \\ Edizione digitale \\ URL: http://journals.openedition.org/studifrancesi/28026 \\ DOI: $10.4000 /$ studifrancesi.28026 \\ ISSN: 2421-5856

\section{Editore} \\ Rosenberg \& Sellier

\section{Edizione cartacea} \\ Data di pubblicazione: 31 décembre 2006 \\ Paginazione: 637 \\ ISSN: 0039-2944

\section{Notizia bibliografica digitale} \\ Emanuele Kanceff, «Le pays dans la poésie de Char de 1946 à 1970, «René Char», 1. Texters réunis par \\ Patrick Née et Danièl Leclair », Studi Francesi [Online], 150 (L | III) | 2006, online dal 30 novembre 2015, \\ consultato il 08 novembre 2020. URL : http://journals.openedition.org/studifrancesi/28026 ; DOI : \\ https://doi.org/10.4000/studifrancesi.28026
}

\section{Questo documento è stato generato automaticamente il 8 novembre 2020}

\section{cc) (†)}

Studi Francesi è distribuita con Licenza Creative Commons Attribuzione - Non commerciale - Non opere derivate 4.0 Internazionale. 


\title{
Le pays dans la poésie de Char de 1946 à 1970, «René Char», 1. Texters réunis par Patrick Née et Danièl Leclair
}

\author{
Emanuele Kanceff
}

\section{NOTIZIA}

AA. VV., Le pays dans la poésie de Char de 1946 à 1970, «René Char», 1. Texters réunis par Patrick NÉE et Danièl LECLAIR. Paris-Caen, Lettres Modernes Minard, 2005, pp. 234.

1 Allo squisito poeta di Vaucluse è dedicata una serie della «Revue des Lettres Modernes» che nasce con questo volume. Di fronte alla vastità tematica di una delle più importanti opere poetiche del Novecento, la scelta del presente tema sembra più che mai opportuna e significativa, sia per la sua iscrizione centrale nel complesso dell'opera, sia per la possibilità che offre di istituire un dialogo critico fertile tra lettori e critici. Otto studi compongono l'ossatura di questo volume, alcuni dei quali si riferiscono ad un'opera di Char in particolare, senza escludere riflessioni comparatistiche: altri, invece, affrontano temipiù generalilegati al paese-paesaggio e ai problemi critici che ne derivano. Ne deriva una interessante visione del "ritorno" di Char al paese natale, in cui ritorno non è inversione di cammino ma approfondimento, migliore comprensione, più profondo legame d'affetto e più suggestiva dimensione evocatrice. 